\title{
10. INTERSTITIAL WATER STUDIES, LEG 48
}

\author{
R. Ellis, J. Pine, and J. M. Gieskes, Scripps Institution of Oceanography, La Jolla, California
}

\begin{abstract}
Interstitial water studies on sites drilled during Leg 48 indicate that (1) complex dissolved sulfate profiles exist in those sites with rapid Quaternary sedimentation, (2) calcium and magnesium gradients in sites on the Rockall Plateau are linearly correlated and indicate the importance of reactions in the strata underlying the deepest samples (these reactions probably involve alteration reactions of volcanic debris), (3) strontium gradients reflect carbonate recrystallization processes, and (4) dissolved silica reflects the presence of biogenic silica.
\end{abstract}

\section{INTRODUCTION}

During Leg 48, interstitial waters were extracted at all sites onboard D/V Glomar Challenger. The samples were analyzed onboard (J.P.) for titration alkalinity and dissolved calcium, magnesium, and chloride, and the acidified samples were further analyzed in our laboratory for potassium, silica, strontium, and sulfate (R.E.). In this report, we present the observed data, with some tentative interpretations. None of the sites drilled reached igneous basement, a fact that makes interpretation difficult, particularly since concentration gradients suggest that reactions in deeper, uncored strata may be responsible for them.

\section{METHODS}

Analyses were carried out using the techniques described by Gieskes (1974), with some minor modifications. Data for dissolved potassium show rather large inaccuracies, due to malfunctions in our flame emission analysis system. As no consistent trends occur in dissolved potassium, this has no serious effect on our interpretations.

\section{RESULTS}

The data are presented in Table 1 and in Figures 1 to 5 .

\section{DISCUSSION}

\section{Sites 400-402 (Bay of Biscay)}

Sites 400 and 402 are characterized by exceptionally high Quaternary sedimentation rates of 6 to $8 \mathrm{~cm} / 1000$ years. Typically, these sites indicate a maximum in alkalinity (Figure 1, Table 1) and show concentrations of dissolved calcium of less than the seawater concentration in the upper section. This is due to the precipitation of calcium carbonate resulting from the production of bicarbonate ions during the sulfate reduction process (c.f., Gieskes, 1975). Concentration gradients in calcium and magnesium are complex and do not lend themselves to ready interpretation. The data for dissolved strontium show large increases, which are related to carbonate recrystallization processes (Gieskes, 1975; Sayles and Manheim, 1975).

Of some interest are the depth distributions of dissolved sulfate. At Site 400 , a clear minimum occurs in the rapidly deposited Quaternary section, indicating almost complete depletion of dissolved sulfate. At 400 meters, a maximum occurs, followed by a gradual decrease downward. This can best be understood in terms of the continued reduction of sulfate in the deeply buried carbonaceous sediments (below $700 \mathrm{~m}$ ). That such processes can still occur at great depth was already shown at Site 386 (Leg 43) by Miller et al. (in press). Subsequently, the rapidly deposited Quaternary section has imposed the more complex sulfate distribution. Clearly, no steady state has been reached in this site. Such complex patterns have been observed previously, e.g., in Site 241 (Gieskes, 1974) and Site 336 (Gieskes et al., 1979).

Dissolved silica data reflect mainly the presence or absence of biogenic silica.

\section{Sites 403 and 404 (Rockall Plateau)}

Sedimentation rates at these two sites have been less than $2.5 \mathrm{~cm} / 1000$ years during the last 10 million years. Consequently, sulfate depletions are moderate (Figures 2 and 3) and only slight maxima occur in the alkalinity-depth profiles. Data quality in Site 403 is superior and indicates a good linear correlation between calcium and magnesium, with $\Delta \mathrm{Ca} /$ $\Delta \mathrm{Mg}=1.15$ (Figure 2). The concentration-depth profiles of calcium and magnesium suggest that these gradients are essentially diffusional in nature and that they are probably due to reactions occurring deeper in the site, perhaps in the underlying tuffs and volcanic sandstones. Measurements of formation factors (by electrical conductivity) would be helpful in confirming this opinion (McDuff and Gieskes, 1976).

The dissolved strontium profile shows a clear maximum at about 150 to 170 meters, i.e., in the Miocene nannochalks. Clearly, this strontium profile is related to carbonate recrystallization processes, and below 200 meters it indicates that diffusion occurs to an unidentified sink in the deeper sediments. The calcium and magnesium gradients do not appear to have any relation to the strontium profile. We submit that the concentration changes in calcium and magnesium are related to alteration reactions involving volcanic material, much in the way that has been suggested previously by Lawrence et al. (1975), Gieskes et al. (1975), and Perry et al. (1976).

Site 404, drilled near Site 403, shows similar features. We suggest that the magnesium concentration at 202 meters is in 
TABLE 1

Interstitial Water Data, Leg 48

\begin{tabular}{|c|c|c|c|c|c|c|c|c|c|c|}
\hline Core-Section & $\begin{array}{l}\text { Depth } \\
(m)\end{array}$ & $\mathrm{Na}^{\mathrm{a}}$ & $\kappa^{\mathrm{a}, \mathrm{b}}$ & $\mathrm{Mg}^{\mathrm{a}}$ & $\mathrm{Ca}^{\mathrm{a}}$ & $\mathrm{Sr}^{\mathrm{a}}$ & $\mathrm{Cl}^{\mathrm{a}}$ & $\mathrm{SO}_{4}{ }^{\mathrm{a}}$ & $A l k^{C}$ & $S i^{d}$ \\
\hline \multicolumn{11}{|l|}{ Hole $400 \mathrm{~A}$} \\
\hline 2.4 & 90 & & 15 & 35.8 & 3.7 & .35 & 558 & & 20.0 & \\
\hline $6-2$ & 125 & 464 & 15 & 45.5 & 5.6 & .47 & 563 & 1.8 & 16.4 & 378 \\
\hline $12-6$ & 188 & 478 & 11 & 41.5 & 9.3 & .83 & 572 & 2.9 & 14.0 & 509 \\
\hline $18-4$ & 242 & 471 & 16 & 41.6 & 12.6 & 1.06 & 564 & 11.3 & 10.3 & \\
\hline $24-5$ & 300 & 469 & 13 & 44.2 & 15.7 & 1.04 & 565 & 16.6 & 5.05 & \\
\hline $35 \cdot 2$ & 400 & 470 & 14 & 43.3 & 21.7 & 1.10 & 572 & 19.3 & 5.87 & \\
\hline $40-1$ & 446 & 454 & 14 & 36.2 & 27.7 & 1.00 & 568 & 12.8 & 4.34 & 816 \\
\hline $45-4$ & 498 & 454 & (12) & 37.3 & 31.4 & 1.14 & 572 & 14.3 & 4.30 & 1230 \\
\hline $51-5$ & 557 & 452 & (12) & 35.9 & 32.9 & 0.87 & 575 & 12.8 & 2.22 & \\
\hline $56-1$ & 600 & & (21) & 30.4 & 29.5 & 0.77 & 574 & & 4.28 & 510 \\
\hline $62-5$ & 661 & 460 & (12) & 37.6 & 26.6 & 0.81 & 584 & 8.4 & 1.60 & 359 \\
\hline $68-2$ & 714 & & (19) & 31.2 & 28.6 & 0.87 & 523 & & .82 & \\
\hline \multicolumn{11}{|l|}{ Hole 401} \\
\hline 1.4 & 6 & 486 & 15 & 51.3 & 11.0 & & 567 & 27.4 & 4.03 & 184 \\
\hline $5-4$ & 118 & 484 & 13 & 47.8 & 15.7 & 0.16 & 571 & 25.3 & 2.24 & \\
\hline $10-5$ & 168 & 493 & 12 & 46.7 & 16.2 & 0.17 & 580 & 24.6 & 1.25 & 573 \\
\hline $16-2$ & 220 & 453 & (17) & 45.6 & 16.6 & 0.06 & 544 & 24.3 & 1.74 & 1090 \\
\hline \multicolumn{11}{|l|}{ Hole 402} \\
\hline $1-2$ & 3 & 463 & 16 & 48.0 & 8.7 & 0.08 & 540 & 21.6 & 9.58 & 795 \\
\hline $5-2$ & 130 & 460 & is & 45.5 & 8.6 & 0.09 & 546 & 16.6 & 3.82 & \\
\hline \multicolumn{11}{|l|}{ Hole 402A } \\
\hline $1-2$ & 140 & 462 & 13 & 46.3 & 9.8 & 0.18 & 544 & 19.2 & 4.90 & \\
\hline $12-2$ & 243 & 445 & (17) & 45.6 & 14.7 & 0.34 & 540 & 20.1 & 2.92 & 389 \\
\hline $18-3$ & 302 & & (17) & 40.2 & 20.0 & 0.54 & 555 & & 2.20 & 326 \\
\hline $30-3$ & 417 & & $(10)$ & 37.6 & 22.7 & $(0.78)$ & 541 & & 0.77 & \\
\hline \multicolumn{11}{|l|}{ Hole 403} \\
\hline $2-5$ & 12 & 497 & 11 & 51.5 & 10.9 & 0.16 & 575 & 27.5 & 2.68 & \\
\hline $7-1$ & 53 & 491 & 13 & 47.5 & 14.8 & 0.32 & 578 & 24.2 & 2.91 & 558 \\
\hline $12-6$ & 108 & 499 & 12 & 43.7 & 18.4 & 0.72 & 586 & 23.8 & 3.38 & 695 \\
\hline $18-2$ & 159 & 478 & 14 & 41.0 & 21.3 & 0.83 & 574 & 20.4 & 3.27 & \\
\hline $26-2$ & 235 & 475 & 10 & 38.5 & 24.8 & 0.54 & 567 & 22.0 & 2.27 & \\
\hline $34-4$ & 314 & 481 & 13 & 33.5 & 30.9 & 0.31 & 584 & 18.8 & 1.30 & \\
\hline 39.2 & 359 & 485 & 11 & 30.8 & 35.1 & 0.15 & 585 & 21.2 & 0.80 & 117 \\
\hline \multicolumn{11}{|l|}{ Hole 404} \\
\hline $2-4$ & 27 & 493 & 13 & 49.9 & 11.8 & 0.22 & 576 & 26.1 & 2.02 & \\
\hline $4-1$ & 172 & 493 & 11 & 44.3 & 17.9 & 0.54 & 579 & 24.2 & 2.52 & \\
\hline 7.2 & 202 & 501 & 11 & 32.9 & 23.2 & 0.63 & 572 & 25.9 & 2.01 & 697 \\
\hline $17-3$ & 298 & & 13 & 26.7 & 44.1 & 0.23 & 540 & & 0.91 & 65 \\
\hline $22-4$ & 347 & 410 & (15) & 23.8 & 50.4 & 0.06 & 557 & 17.5 & 0.92 & 137 \\
\hline \multicolumn{11}{|l|}{ Hole 405} \\
\hline $1-5$ & 7 & 469 & 13 & 55.0 & 10.3 & 0.08 & 556 & 26.7 & 2.93 & 292 \\
\hline $8-3$ & 69 & 473 & 13 & 53.2 & 12.2 & 0.14 & 564 & 24.7 & 3.12 & \\
\hline $13-3$ & 117 & 486 & 13 & 51.7 & 13.5 & 0.17 & 575 & 25.8 & 2.59 & 581 \\
\hline $16-3$ & 145 & 485 & 12 & 49.4 & 15.4 & 0.22 & 574 & 25.3 & 2.59 & 700 \\
\hline $19-3$ & 173 & 486 & 14 & 48.7 & 15.5 & $(0.05)$ & 575 & 25.8 & 1.64 & \\
\hline $31-3$ & 288 & 448 & (18) & 39.2 & 23.7 & 0.31 & 558 & 17.0 & 0.82 & 410 \\
\hline $40-3$ & 372 & 489 & 10 & 18.5 & 40.8 & 0.26 & 575 & 21.1 & 0.45 & 226 \\
\hline \multicolumn{11}{|l|}{ Hole 406} \\
\hline 1.2 & 3 & & 13 & 52.4 & 10.6 & & $\$ 60$ & & 3.93 & \\
\hline $2 \cdot 3$ & 66 & 479 & 13 & 46.2 & 8.6 & 0.43 & 563 & 18.0 & 3.75 & 531 \\
\hline $4-2$ & 216 & 456 & 14 & 33.3 & 17.3 & 1.24 & 551 & 7.6 & 7.82 & \\
\hline $6-1$ & 329 & & 12 & 28.1 & 18.0 & 1.27 & 575 & & 3.89 & 902 \\
\hline $13-4$ & 457 & 513 & 16 & 20.7 & 23.5 & 1.20 & 588 & 14.7 & 1.65 & 796 \\
\hline $20-2$ & 521 & & 13 & 19.2 & 25.2 & 1.36 & 584 & & 1.91 & 979 \\
\hline $29-3$ & 608 & 493 & 13 & 17.4 & 28.3 & (1.46) & 575 & 11.7 & 1.94 & 1110 \\
\hline $34-1$ & 652 & & (8) & 14.8 & 30.2 & .62 & 586 & & 0.84 & \\
\hline
\end{tabular}

error, so that a reasonably simple concentration gradient results, with a linear correlation to that of calcium. Again, a maximum in dissolved strontium occurs in the dissolved strontium profile near the lower end of the Miocene carbonate sediments. We submit that, again, alterations of volcanic material in the underlying sediments are the main cause of the observed gradients in calcium and magnesium.

\section{Site 405}

In Site 405 , the Quaternary section, i.e., the upper 40 to 50 meters, has been deposited at sedimentation rates of 2 to 3 $\mathrm{cm} / 1000$ years. Below this, large unconformities characterize the section, and the bulk of the recovered sediment consists of rapidly deposited early Eocene sediments, with silicified mudstones below 3000 meters. Concentration gradients in calcium and magnesium are linearly correlated, with $\Delta \mathrm{Ca} / \Delta \mathrm{Mg}=0.82$. We suggest that the character of the gradients is, again, essentially diffusional in nature, with the slopes of the gradients increasing in the silicified section. Here again, formation factor measurements may be relevant (McDuff and Gieskes, 1976).

The dissolved strontium data show a maximum at the bottom of the carbonate sequence.

\section{Site 406}

Sedimentation rates in Site 406 have been high in the upper 500 meters of the sediment column. This is, again, reflected in a minimum in dissolved sulfate and a maximum in alkalinity. As is usual in such cases, the concentration gradients in calcium and magnesium are complex and difficult to interpret.

\section{ACKNOWLEDGMENTS}

This investigation was generously supported by NSF Grant OCE76-20151 (J.M.G.).

\section{REFERENCES}

Gieskes, J. M., 1974. Interstitial water studies, Leg 25. In Simpson, E. S. W., Schlich, R., et al., Initial Reports of the Deep Sea Drilling Project, v. 25, Washington (U.S. Government Printing Office), p. 361.

, 1975. Chemistry of interstitial waters of marine sediments, Ann. Rev, Earth Planet. Sci., v. 3, p. 433.

Gieskes, J. M., Kastner, M., and Warner, T. B. W., 1975. Evidence of extensive diagenesis, Madagascar Basin, Deep Sea Drilling Site 245, Geochim. Cosmochim. Acta, v. 39, p. 1385.

Gieskes, J. M., Lawrence, J. R. and Galleisky, G., 1979. Interstitial water studies, Leg 38. In Talwani, M., Udintsev, G., et al., Initial Reports of the Deep Sea Drilling Project, Supplement to Volumes 38, 39, 40, and 41: Washington (U.S. Government Printing Office), p. 121-133.

Lawrence, J. R., Gieskes, J. M., and Broecker, W. S., 1975. Oxygen isotope and cation composition of DSDP pore waters and the alteration of Layer II basalts, Earth Planet. Sci. Lett., v. 27 , p. 1 .

McDuff, R. E. and Gieskes, J. M., 1976. Calcium and magnesium profiles of DSDP interstitial waters: Diffusion or reaction?, Earth Planet. Sci. Lett., v. 33, p. 1.

Miller, R., Lawrence, J. R., and Gieskes, J. M., in press. Interstitial water studies, Sites 386 and 387, Leg 43. In Tucholke, B., Vogt, P., et al., Initial Reports of the Deep Sea Drilling Project, v. 43; Washington (U.S. Government Printing Office).

Perry, E., Gieskes, J. M., and Lawrence, J. R., 1976, Mg, Ca, and $\mathrm{O}^{18} / \mathrm{O}^{16}$ exchange in the sediment-pore water system, Hole 149 , DSDP, Geochim. Cosmochim. Acta, v. 40, 413.

Sayles, F. L. and Manheim, F. T., 1975. Interstitial solutions and diagenesis in deeply buried marine sediments: Results from the Deep Sea Drilling Project, Geochim. Cosmochim. Acta, v. 39, p. 103. 


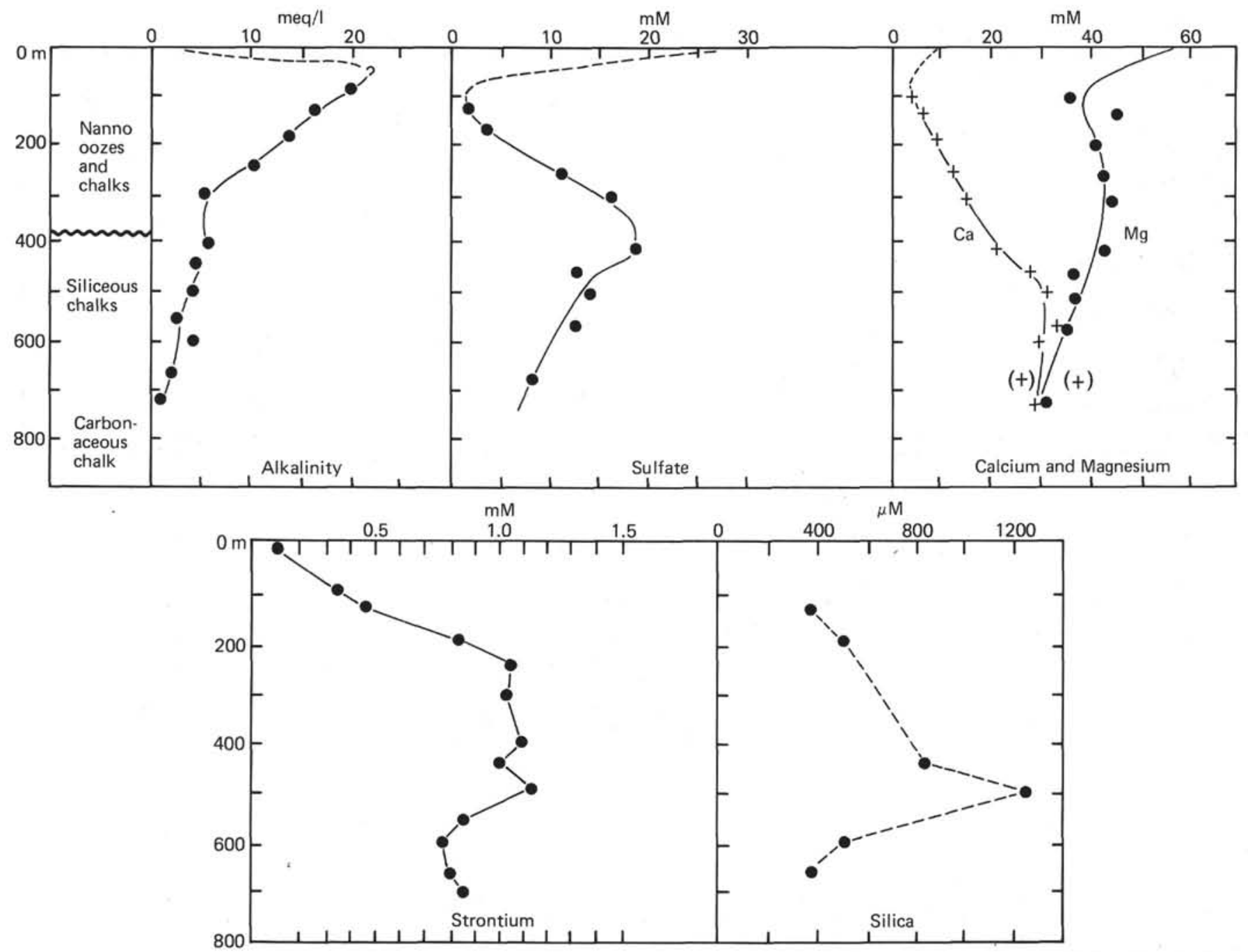

Figure 1. Interstitial water data, Site 400. 

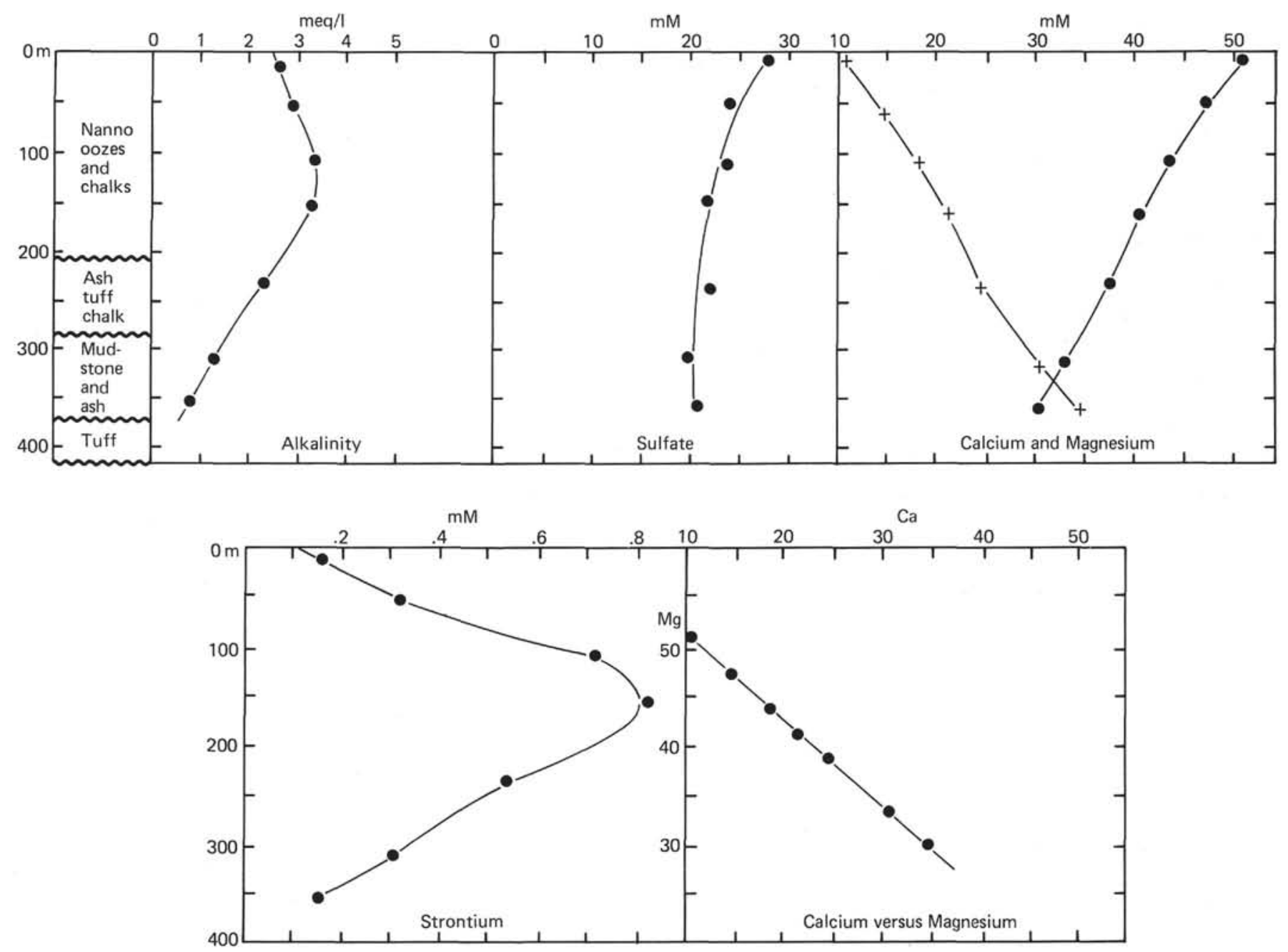

Figure 2. Interstitial water data, Site 403. 

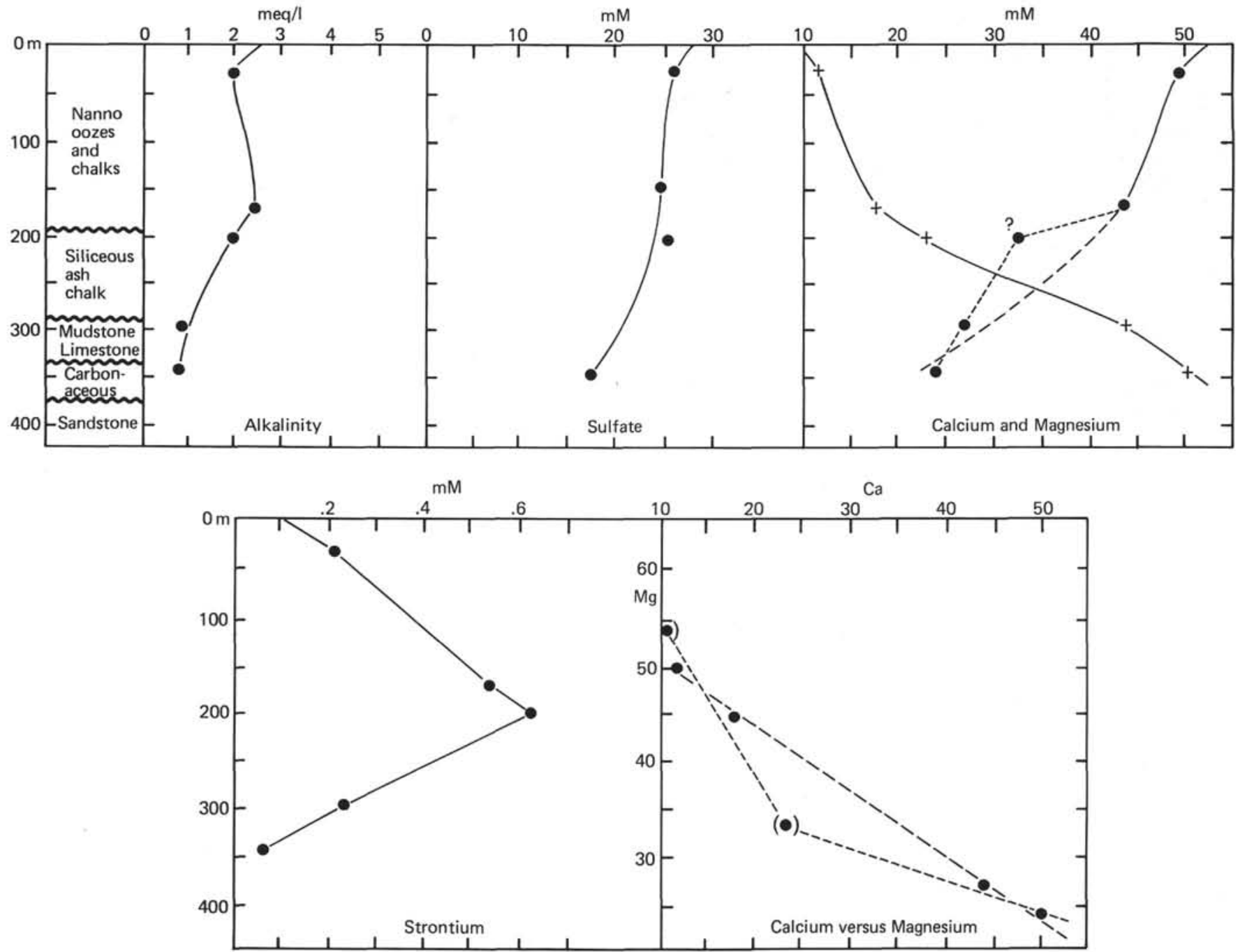

Figure 3. Interstitial water data, Site 404. 

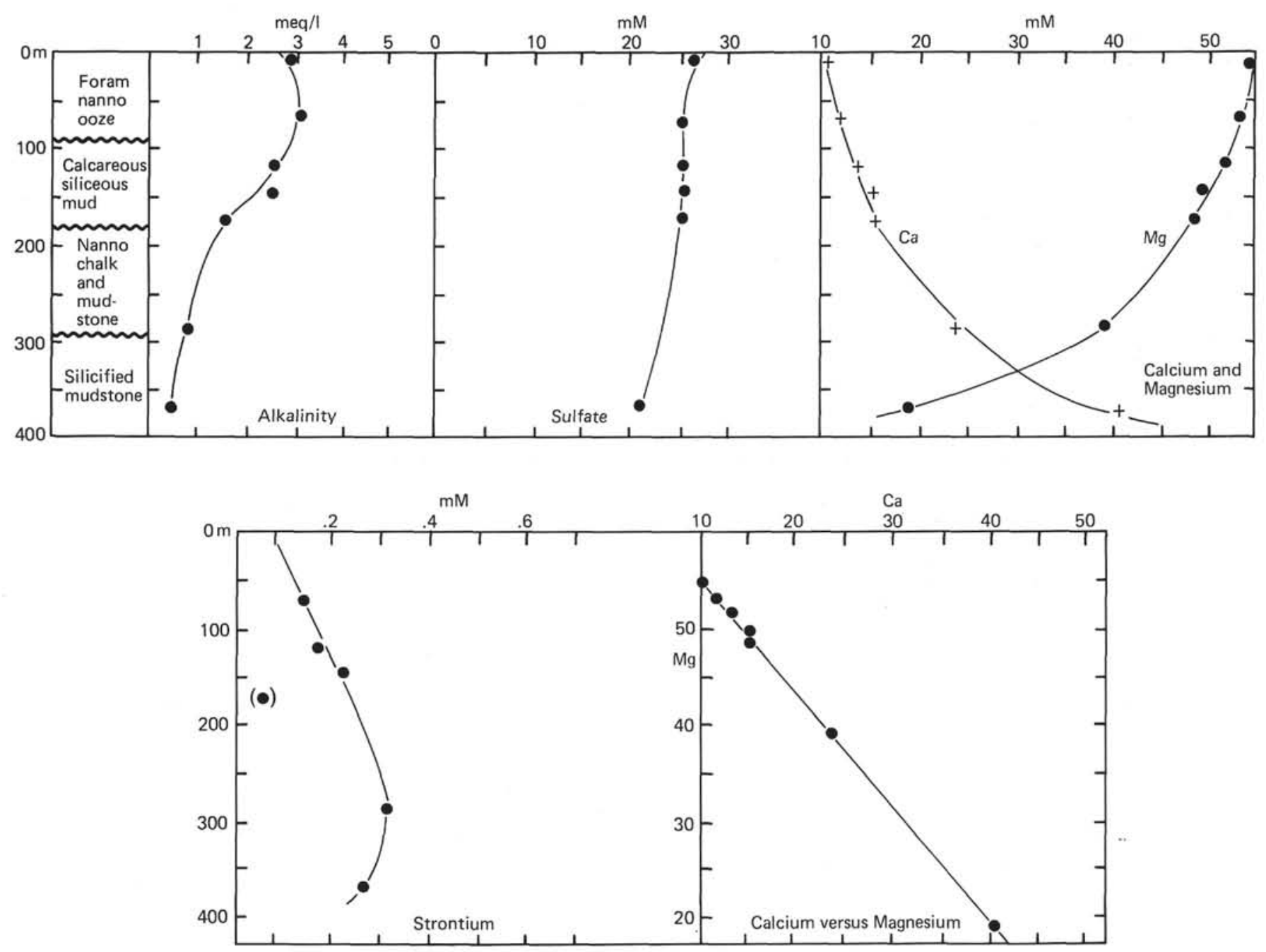

Figure 4. Interstitial water data, Site 405. 

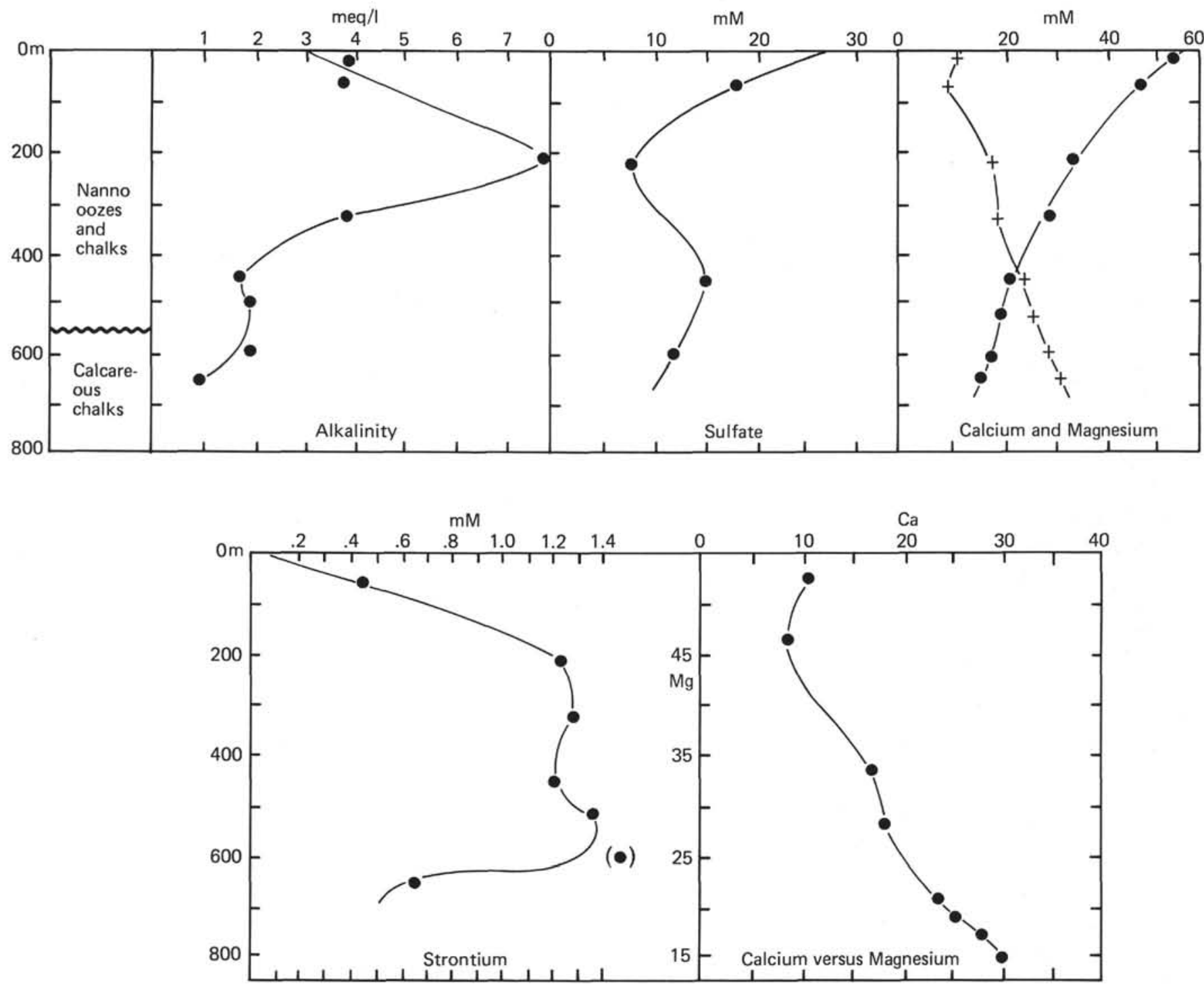

Figure 5. Interstitial water data, Site 406. 